\title{
Zakat Management Strategy in Poverty Alleviation: Study of Zakat Collecting Institutions in Indonesia
}

\author{
Engkos Koswara \\ UIN Sunan Gunung Djati Bandung, Indonesia \\ Email: e.koswara@gmail.com
}

\begin{abstract}
In Islam, one of the efforts to overcome poverty is through zakat. Therefore, zakat must be managed professionally and professionally, so zakat can be taken part in realizing Islamic ideas for the welfare of society. one of the institutions that are proven capable of managing zakat that is trusted, transparent, and professional is Rumah Zakat Indonesia (RZI). This study aims to describe the management of zakat conducted by Rumah Zakat Indonesia in alleviating poverty through community empowerment. Using socio-economics, and interpreting it into a form of complete research information.
\end{abstract}

Keywords: Zakat, poverty, empowerment.

\section{A. INTRODUCTION}

In the context of addressing the development of poverty in Indonesia, during 1976-1996 the number of poor people dropped dramatically from 54 million people or $40 \%$ of the population (1976) fell to 22.5 million people or about $11.3 \%$ (1996). Since the economic crisis in 1998 increased by 400\%, in 1997 from 22 million to 80 million (BPS, 2005). In Central Java, poverty conditions on average showed an increase from 5.9 million in 2003 to 6.9 million in 2006 (Susenas). Increasing the number of poor people is a great danger for humanity and not a few people who fall into civilization only because of poverty, therefore the policy is needed in eradicating poverty.

In Islam, the eradication of poverty is institutionalized in one of its pillars, namely zakat (Qadir, 2001), therefore a zakat trustee is needed that is trustworthy, transparent, and professional. One of the many organizations that manage zakat effectively, efficiently and transparently is Rumah Zakat Indonesia (RZI). To maximize community empowerment, service units were established as a center for optimization of 4Care: 4 Champion Schools, 5 Houses Free Maternity, 13 Free Maternity Services, 17 Mosaic Sharia Microfinance Institutions (LKMS), and 2 Youth Development Center (YDC) (Bappenas, 1993). At present, there are 64,222 donors joining RZI and supported by 656 amil with functions starting from the back office, funding, to program personnel. So EcoCare through LKMS Mozaik has been able to record 5,550 members, with 912 participants KUKMI (Independent Small Business Group) and a revolving fund valued at Rp 6.4 billion. Likewise, YouthCare has recorded 1,153 volunteers joining 914 active volunteers. 
Volunteer Campus activities that run in 10 cities, rolling out the Community Development curriculum, Emergency Rescue Team, and Community Assistance that provide benefits for 2,112 residents. Do not miss Health Care with 32 ambulance and hearse fleets, 6 mobile clinic mobile fleets, has recorded 9 4,397 participants in Healthy Action Action.

Therefore, research conducted on the management of zakat RZI is very varied, even it seems far from the allocation of conventional zakat distribution which strictly should not move from the eight existing așnaf. This clearly shows that this institution has endeavored that the allocation and distribution of zakat can be implemented effectively, efficiently and on target in poverty alleviation, especially in Central Java Province. From the background of the above problems, the problem of this research is about the factors that influence people's motivation to distribute zakat (and also infaq, shadaqah, and waqf) in Indonesian Zakat Houses and how zakat management is carried out by Rumah Zakat Indonesia (RZI) in alleviation poverty in Central Java.

This research uses a qualitative approach. The research object that will be used as the research area is the Indonesian Zakat House in Central Java as the boundary of the research area by looking at the management and distribution of zakat as an effort to alleviate poverty. This research is also an evaluative study in terms of its shape. Therefore, this study will analyze the distribution of zakat in poverty alleviation efforts in Central Java.

This study will only examine a portion of the population of all members of the Indonesian Zakat House (RZI) which includes muzakki, managers and mustahiq zakat. The method of determining the sample to be used is purposive sampling. Samples were taken from some who could represent to provide information that would be needed from both the muzakki, mustahiq and zakat managers who were determined as objects of this study.

The respondent from Rumah Zakat Indonesia is the executive board which includes the chairman, secretary, treasurer, and all its divisions. In addition, interviews involved elements of the government to obtain data about the condition of the study area, in addition to obtaining data from muzakki and mustahiq groups that had been determined as respondents. The analysis functions to simplify the data in a form that is easier to read and interpret (Effendi, 1988). The analysis used in this study is descriptive qualitative analysis, namely, research that aims to collect data collected for analysis and then the data are interpreted then a conclusion is drawn.

\section{B. LITERATURE REVIEW}

\section{Poverty Concept}

According to UNICEF, poverty as a material lack of material minimum human needs including health, education and other services can prevent people from poverty. Ravallion stated that in the 1970s, a poverty line was formulated to determine the min- 
imum income level that was sufficient to meet the basic physical needs of everyone in the form of food, clothing, and housing so that they could ensure their survival (Ravallion, 2001).

Blank outlines the concepts of local characteristics that have the potential to influence poverty levels and the policies that affect them. These characteristics are the natural environment, economic structure, institutionality and characteristics of the population of a local area (Blank, 2004). The World Bank explains several characteristics of poor people including poor nutrition, low education, life expectancy, and housing standards. Ten years later the World Bank issued a report on combating poverty which emphasized another characteristic, namely that they generally had a weak position in voicing their interests and were vulnerable to economic turmoil (World Bank, 2001).

The National Development Planning Agency (Bappenas) explains poverty is a situation of shortages that occurs not because of the wishes of the poor, but because it cannot be avoided with the power available to him (Bappenas, 1993). Another opinion expressed by Ali in Setyawan (2006) stated that poverty is a gap or gap between the main values are accumulated by fulfilling the need for these values appropriately. According to Chambers in Ali (2003), there are five disadvantages that surround the lives of the poor, namely:

a. Poverty, has the following signs: decrepit houses and made of low-quality building materials, very minimal equipment, the family economy is characterized by the economy of digging holes closed holes and uncertain income;

b. The problem of vulnerability (vulnerability), this vulnerability can be seen from the inability of poor families to deal with emergency situations. Hard-won economic improvements can sometimes disappear when illness comes to their families who need a large number of medical expenses;

c. The problem of powerlessness. The form of the helplessness of the poor is reflected in their inability to face the elite and the bureaucracy in determining decisions concerning their destiny, without giving an opportunity to actualize themselves;

d. Weak physical endurance (physical weakness) due to low consumption of food both quality and quantity so that their nutritional consumption is very low which results in their low productivity and

e. The problem of isolation, physical isolation is reflected in pockets of poverty that are difficult to reach, while social isolation is reflected in the closedness in the integration of the poor with the wider community.

Meanwhile, according to Kuncoro (2013) that from an economic standpoint, poverty occurs because of three things, including the inequality of resource ownership patterns that lead to unequal income distribution, differences in quality of human resources, low quality of human resources indicate low productivity, low wages and the difference in access and capital. The three causes of poverty mentioned above lead to 
the vicious circle of poverty theory.

The existence of underdevelopment, underdevelopment, market imperfections, lack of capital causes low productivity. The low productivity causes the low income they receive. Low income will have implications for low savings and investment, the low investment will result in underdevelopment and so on. The logic of thought proposed by Nurkse, quoted by Kuncoro, suggests that a poor country is poor because it is poor (Qadir, 2001).

\section{Zakat}

In terms of the language of the word, zakat is the basic word of zakat which means holy, blessing, growth, and praise. Whereas in terms of fiqh, zakat means a certain amount of assets that Allah requires to be handed over to the person who has the right to receive them, in addition to meaning issuing a certain amount of itself (Qhardawi, 1995). According to the sharia etymology (term), zakat is the name for a certain amount of property that has reached certain conditions which Allah has obliged to be issued and given to those who are entitled to receive it.

Zakat is one of the pillars of Islam with the dimension of social justice. In etymology zakat means holy, good, growing, clean and developing, and in terms of zakat is a number of assets that are required by God to be taken from the property of certain people (aghniya $\left.\bar{a}^{\prime}\right)$ to give to those who are entitled to receive it on conditions certain conditions (Qhardawi, 1995; Sabiq, 1982; Jurjani, 1983). The essence of zakat is the management of funds taken from aghniy $\bar{a}^{\prime}$ to be handed over to those entitled to receive it and aims to prosper the social life of the Muslim community. This is at least reflected in the words of Allah relating to the commandments zakat. In addition, it was also strengthened by the order of the Prophet Muhammad SAW to Mu'adz bin Jabal who was ordered to take and collect the wealth (zakat) from rich people who were then returned to the poor of their group. Therefore it can be concluded that the strategic role of zakat for the community is as follows: (1) Capital, according to research conducted by PIRAC (Public Interest Research and Advocacy) that the potential for zakat in Indonesia ranges from 19-20 trillion per year, a sufficient capital for community development, and that amount will be even greater along with the increasing awareness of Muslims about zakat and the ability of fiqh to describe new types of businesses / income included as zakat objects; (2) Social Justice, the implementation of zakat generates social justice in society, in addition to the emergence of sources of receiving zakat from new types of income also because zakat is empowered for the benefit of the poor who are served by the rich in in their midst; (3) Social Equilibrium, social equilibrium built by zakat makes the poor get their share obtained from the wealth of wealthy people around them, so that social inequality is not adrift high; (4) Social Guarantee, the community feels guaranteed when zakat can be realized in its form, so that the poor do not have to worry about seeking treatment or getting education services because there is no security deposit for 
example; (5) Social Safety, in fact with the accumulation of large zakat funds in addition to development capital, is also beneficial for standby funds that are ready to be used at any time, especially against unexpected events, natural disasters, fires, floods and others (Amanah, 2010).

\section{RESULTS AND DISCUSSION}

\section{A Brief History of the Rumah Zakat Indonesia (RZI)}

In 1998, Abu Syauqi, one of the young preachers of Bandung, together with several colleagues in the Majlis Ta'lim Ummul Quro study group agreed to form a social institution that was concerned with humanitarian assistance. On July 2, 1998, an organization called the Ummul Quro Social Wallet (DSUQ) was formed, which was located on Jl. Turangga No. 33 Bandung as well as a place of study. Recitation congregation is growing, then used Al-Manaar Mosque Jl. Puter Bandung as a place of routine study.

In 1999, continued community support encouraged better management of the organization. The secretariat office moved to Jl. Dederuk No. 30 Bandung, approaching the recitation forum at Al-Manaar Mosque. Achievement of donations during 1998-1999 collected as much as Rp. 0.8 billion. In 2000, public interest in the need for humanitarian organizations increased. The community views that this social mission is important to be continued even for a wider gait. Initiated orphan and du'afā 'scholarship programs, health services, rehabilitation of the urban poor, etc. The division began with the opening of a Yogyakarta branch office, May 2000 on Jl. Veteran No. 9. The Bandung branch was moved to the initial secretariat on Jl. Turangga No. 33 Bandung. Donations during the year collected Rp. 2.1 billion. In 2001 (February), the Jakarta branch office was officially established on Jl. Ekor Kuning Rawamangun, East Jakarta. The donation collection was Rp. 2.19 billion. In 2002, the institution's identity as an amil zakat institution was strengthened. Jakarta Branch Office moved to Jl. Taruna No. 43 Pulogadung. Donation receipts increased to Rp. 4 billion. In 2003, DSUQ changed its name to Rumah Zakat Indonesia DSUQ, in line with the decree of the Minister of Religion of the Republic of Indonesia No. 157 on March 18, 2003, which certified this organization as the National Amil Zakat Institution. In May, Rumah Zakat Indonesia DSUQ was present in the capital of East Java, Surabaya. Donations continue to increase to Rp. 6,46 Billion.

In 2004, the Tangerang Branch Office was established. The expansion began to spread to Sumatra with the establishment of the Pekanbaru Branch Office, Riau, the start of the development of information technology systems to improve service quality, so that almost all branch offices have been connected online on the website www.rumahzakat.org replacing the previous site address at www.rumahzakat.net, strengthens the institution's branding under the name Rumah Zakat Indonesia. Community trust is growing, donations collected as much as Rp. 8.92 billion. In 2005, branch growth increased rapidly. The Aceh tsunami that occurred on December 26, 2004, opened access to the Indonesian Zakat House more in Sumatra. New branches were 
opened, Aceh, Medan, Padang, Palembang and Batam branches were established. In Java, Semarang branch offices were also established, plus a network of Supporting Branch Offices in Bekasi, Bogor, Depok, South Jakarta, Cirebon, and Solo. The Pekanbaru branch also expanded by having Duri and Dumai Sub-Branch Offices. Institutional information systems began to enter the online network. Start online transactions, attendance online, and some financial software.

Donations received increased sharply especially from community assistance for the post-tsunami rehabilitation program in Aceh, recorded Rp. 45, 26 billion donations were collected. In 2006, the top regeneration of the leadership was transferred from Ustadz Abu Syauqi to Virda Dimas Ekaputra. The new chapter of history 'Transformation from Traditional Corporate to Professional Corporate' begins. Zakat awareness continues to be encouraged by releasing the campaign: "When Zakat Being Life-style." The program "The Title of Zakat Culture (GBZ) Towards Indonesia Conscious Zakat 2008" was first held in 6 cities. The donation was successfully collected as much as Rp. 29.52 billion. In 2007, the development of the program was further refined, including by changing the term Empowering Department to the Program Directorate. Implementation of the program began to focus on the cone to four mains namely EduCare, HealthCare, YouthCare, and EcoCare. Program management is carried out with an integrated and sustainable concept based on community.

ICD is a place that is focused on integrated distribution through education, health, youth training, and integrated community-based economic empowerment. With Mustahiq Relation Officer as accompanying HR, ICD is the center for program distribution so that it is more measurable, and controlled. Also this year Rumah Zakat Indonesia expanded its educational program services by holding a free Champion Primary School. The best teachers are chosen to educate the nation's future leaders. The communication program was developed more massively through television. The inaugural TV Commercial was launched titled "I Believe Rumah Zakat" by cooperating with endorser Helmy Yahya. The event "Zakat Culture Degree (GBZ) Towards Indonesia Awareness of Zakat 2008" was held again, this time held in 10 cities. Obviously the results of communication and focusing positive positive correlation program on the achievement of donations, collected Rp. 50.16 billion.

In 2008, Rumah Zakat Indonesia has a strong desire to strengthen empowerment programs. The support and trust of the community strengthened the institution to increasingly focus on a grand civilization design that had been dreamed of from the beginning, namely "transformation of mustahiq to muzakki". A concrete manifestation of the institution's business is to expand the development network of small and micro businesses in 18 cities. Not only that, but Rumah Zakat Indonesia also organizes motivational and skills training in the Youth Development Center center. This motivational training plays an important role because the characters, mindset, and counterproductive attitudes contribute greatly to the permanence of poverty. And no less important is 
community assistance carried out by 28 Mustahiq Relation Officers (MRO) supported by volunteers.

Learning to become a trustworthy and professional organization continues to be carried out, one of them is by strengthening Human Capital programs. Launched programs such as AZIE (Amil Zakat Indonesia's Executive), ADP (Amil Development Program), ACTPRO (Acceleration Program) and so on. This capacity-building activity has proven to be effective in meeting the demands of the profession and the community. Trust continues to grow, from the achievements of donations successfully collected donations of Rp. 71.40 billion. To provide wider education to the public about zakat and philanthropy, the Roadshow of the Zakat Culture Title was held, this time in 19 cities. 2009 became the first year after the first 10 years of the Rumah Zakat Indonesia milestone. In order to strengthen the organization, new empowerment organizations have been strengthened, namely: Rumah Sehat Indonesia (manager of health programs), Rumah Champion Indonesia (manager of educational programs), Rumah Mandiri Indonesia (manager of economic independence programs). Increasing the number of service units continues to be carried out, until the end of the year there have been $8 \mathrm{Cham}$ pion Schools, 7 Free Maternity Homes. 2009 can be called an expansion year, considering that in the first semester 14 new branches were opened immediately, thus increasing the total network of 45 offices. Better management has received appreciation from the community. including awards from Karim Business Consulting which placed Rumah Zakat Indonesia as the Best LAZNAS in the ISR Award (Islamic Social Responsibility Award 2009). The award also came from IMZ (Indonesia Magnificence of Zakat) which was awarded the Indonesian Zakat House as The Best Organization in Zakat Development. Achievement of donations is growing better, recorded Rp. 107, 3 billion have been collected and made Rumah Zakat Indonesia as the largest zakat management organization in collecting donations throughout Indonesia.

The global crisis in 2009 is predicted to start recovering in 2010, but social and economic challenges are no easier to deal with. Rumah Zakat Indonesia responded to this by carrying out a series of adaptations and changes towards a global scale organization. On April 5, 2010, a new brand "Rumah Zakat" was officially launched replacing the previous brand "Rumah Zakat Indonesia". By carrying out three new brand values: Trusted, Progressive and Humanitarian, this organization sharpens its character towards "World Class Socio-Religious Non Governance Organization (NGO)". Sharing Confidence was appointed as a positioning. "With a strong conviction to share and create a better global family, Rumah Zakat to make an effort to be a leading organization in the region that ensures effective and sustainable programs empower people to achieve better lives." In order to strengthen this change, the Indonesian Smile Collection Strike movement was also launched, a series of activities to improve Indonesia's Human Development Index (HDI), more specifically in the fields of education, health and living worthiness. 
The history of the Alms Houses in Central Java began with the opening of the Semarang branch office in May 2005 at the same time the Alms Houses of the Solo branch was also opened. The first program to be rolled out is the Scholarship for Orphans and Dhu'afa '/ KSAB Program (Restore the Smiles of the Children of the Nation) and Baksos Alert Healthy and Nutrition Standby. Along with that, the head office brought in an ambulance unit for the free ambulance program for the people of Semarang. The ambulance program is quite populist and is an outstanding branding for the Semarang Branch Rumah Zakat. The support and sympathy of the people of the city of Semarang for trust in the Semarang Branch of Alms Houses increased, in May 2007 there was an RBG (Free Maternity Home) and in 2010 there was also a free Champion Primary School for orphans and 'u'afā'. The programs and services of Rumah Zakat will increasingly revolve along with the trust and support of the people of Semarang. As for the empowerment of KUKMI (Small Medium Enterprises Group), there are 50 who have been accompanied. There is a change in morals and religious awareness and $20 \%$ of the groups assisted by their efforts are getting more advanced and enthusiastic. There is enthusiasm and hope when we help our weak Muslim brothers and sisters, Allah will help and make our work easier.

\section{Factors Affecting Respondents Disbursing ZIS Funds to Indonesian Zakat Houses}

Based on the results of the distribution of the research questionnaire, $32.26 \%$ indicated that the RZI was reliable, and $29.03 \%$ indicated that the RZI was transparent and accountable. The number of respondents stated that RZI can be trusted, because each RZI activity (collection and distribution of ZIS) is always informed transparently and accountably to the media, both the website and other information media, and each donor (muzakki) can easily control ZIS funds, this results in respondents believe in ZIS management at Rumah Zakat Indonesia. In addition, there are several reasons why RZI is trusted by the public:

RZI has been established for almost 11 years and is one of the pioneers in managing zakat, infaq, shadaqah, and Islamic philanthropy professionally, managed as a profession every day, 6 working days, with $90 \%$ of human resources under 35 years, the majority are undergraduate and diplomas from various leading universities.

Indonesia is a maritime and archipelago country therefore RZI is present not only in Java but spreads with the largest network compared to similar management institutions. As of May 2009, RZI had 44 office networks in 38 major cities in Java, Sumatra, Kalimantan, Sulawesi and Papua with a strong and integrated center-branch relationship pattern.

RZI develops zakat, infaq, shadaqah, and other community-based humanitarian fund management, both per district and villages called ICD (Integrated Community Development). Each ICD is handled by at least 1 Mustahiq Relation Officer (MRO) sup- 
ported by 3-5 volunteers who develop 4 main programs; EduCare (focus: basic education), HealthCare (focus: maternal and child health), EcoCare (focus: empowerment and business assistance), YouthCare (focus: youth empowerment and community assistance). Now 227 ICDs have been formed where each ICD is developed from 100 to 200 households, with 14 Integrated Community Development Centers (ICD) spread across 14 cities.

The program developed by RZI is quite simple, populist but felt by the community. This can be seen from excellent programs such as the free hearse program where now there are 45 hearses and ambulances ready to serve the community for free. It is these real programs that will help strengthen 85,057 donors increasingly trust involved in this program through Rumah Zakat Indonesia.

Community charity is utilized optimally and manifestly through the establishment of center programs such as:

a. Eight (8) "Juara" School units (excellent primary schools, free for underprivileged students) in Bandung, Cimahi, Jakarta, Pekanbaru, Surabaya, Yogyakarta, South Jakarta, Medan.

b. Thirteen (13) Children Potential Development Centers (P3A) in almost all RZI branches, with 455 foster children. The EduCare Department of Education regularly manages scholarship benefits for 20,155 foster children. A minimum of once a month is coaching a Kids Learning Center which is participated by 16,124 foster children spread in 228 ICD with the support of 698 active mentors.

c. Seven (7) units of Free Maternity Homes (RBG) in Bandung, Jakarta, Semarang, Yogya, Medan, Pekanbaru, and Surabaya. This year new RBGs will also be opened in four cities. Branches that do not yet have an RBG are now also able to serve maternal and child health through the Free Maternity Services (LBG) program, in collaboration with partner midwives.

d. Eighteen (18) "Mozaik" Sharia Cooperative units in 17 cities.

e. One (1) Youth Development Center unit in Bandung as an entrepreneurship training center for young people who are members of volunteers and Integrated Community Development.

In addition to having to advance zakat management must also continue to be in accordance with the sharia corridor (sharia comply). RZI routinely consults with the Sharia Supervisory Board of the Indonesian Zakat House, Ustadz Kardita Kintabuwana, Lc, MA who is a graduate of Jami'ah al-Islamiyah Madinah and Director of Ma'had al-Imarat Bandung. As well as routinely together Ustadz Dr. Shariah references. Setiawan Budi Utomo, Lc who is also a member of the National Sharia Council-MUI.

Management of public funds is carried out securely supported by modern communication technology connecting all office networks online. Every donation development can be monitored in real-time. At present, a Mushtaq Information System (MUIS) is also being developed in which beneficiaries are fully recorded so that monitoring and 
coaching are easier and more accurate.

A legal entity may be a foundation but a full corporate work culture. Attendance is done online, starting in the morning, entering after the lunch break, until the time of return. Every late fee is varied starting from Rp. 100 thousand to Rp. 750 thousand per day even though it's only 1 second late. The reward and punishment system works well with the support of an online and transparent Human Resource Information System (HRIS) system.

Although primarily targeting the personal segment, RZI has also been trusted by many companies and communities. As of the beginning of March 2009, 460 national and regional companies (with assets of Rp. 500 million and above) joined as partners. RZI also received positive appreciation from the United Nations (UN) in its programs that support the Millennium Development Goals (MDGs).

Donors and the general public can access services easily with a variety of donations. Either via visiting counter, picked up by ZIS Consultant, via ATM, online payment, mobile banking, internet banking, donations via debit cards and credit cards, auto-debit, or donations via SMS. This facility is also supported by the host to host services with banking and payment service partners. Online partners can also consult about zakat and services via the website http://www.rumahzakat.org and SMS center at number 08157300 1555, email center at welcome@rumahzakat.org, call center 0804100 1000.

\section{Management and Distribution of ZIS Funds at Indonesian Zakat Houses in Poverty Alleviation Measures in Central Java}

Management and distribution of ZIS funds at RZI by developing several programs including (1) Community Assistance; (2) Integrated Community Development (ICD); (3) Youth Capacity Building; (4) Disaster Preparedness. ICD (Integrated Community Development) is a superior program developed by Rumah Zakat Indonesia which is a community-based community empowerment center in the sub-district / village area. Each ICD is accompanied by an MRO (Mustahiq Relation Officer) who functions as a mobilizer, mentor, facilitator, dynamist and even the dai who helps ensure that the 4 main RZI family groups are well received in the community. Each MRO lives in the community but manages 100-250 families. Integrated Community Development (ICD) is a multi-aspect approach rolled out by RZI to alleviate the poverty of its musta mustiqs in an integrated manner with a certain regional work base (village scope). In the Province of Central Java in March 2010 there were 5,369 million people (16.56\%). Compared to the poor population in March 2009 which amounted to 5.726 million people $(17.72 \%)$, meaning the number of poor people fell by 356.53 thousand people. This indirectly, RZI plays a role in poverty alleviation in Central Java through the empowerment of ZIS funds. 
The distribution of RZI assistance is carried out through programs in the fields of education, health, youth (volunteerism) as well as economics. The current condition of distribution is still being distributed according to the requirements of each program, this gives difficulties in measuring the success of the program. While the objectives of the ICD program are: (1) Helping people to survive amid the lack of material they have. (2) Monitoring the development of welfare mustahiq during the formation of ICD; (3) Awareness of the community towards local responsibility in alleviating poverty in the region (ICD) (4) The eradication of poverty from the poverty line so that it can change its welfare at the level of muzakki.

RZI has been widely trusted by partners both individuals, institutions or companies (national and regional) RZI also received positive appreciation from the United Nations (United Nations) in its programs that support the Millennium Development Goals (MDGs) in the context of poverty alleviation. Seven of the eight Millennium Development Goals (MDGs) programs have been implemented by Rumah Zakat Indonesia. Among others: eliminating poverty, education for all, gender equality, reducing child mortality, improving maternal health, environmental preservation, global collaboration. Through its programs, Rumah Zakat Indonesia is getting stronger through more detailed monitoring in each integrated empowerment community. It is expected that this effort is in line with the Millennium Development Goals (MDGs) which target in 2015, poverty can be reduced by $50 \%$.

\section{Management and Distribution Model of Zakat Based on Research Re- sults}

RZI controls the distribution of ZIS in poverty alleviation efforts by establishing Standard Operating Procedures (SOP). In addition, each donor program will receive various reports as a form of transparency and accountability in the management and distribution of ZIS at Rumah Zakat Indonesia. For Integrated Community Development (ICD). This program can be offered to corporate donors by carrying out corporate. To control the success of this program and as a form of transparency, the Integrated Community Development (ICD).

The results of the research show that in the management of zakat collected by RZI from an area, the funds are ready to channel it to the region itself. The results of collecting ZIS funds from various ways that make it easy to pay for ZIS, are recorded centrally, with distribution in each of these areas intended to facilitate financial audits in a consolidated and transparent manner. Management funds (amil) generated from the collection can be subsidized to cities in need. The percentage of distribution to the program depends on the evaluation and community needs of the standards used by ZIS. Fund allocations are $12.5 \%$ of managed funds, $10 \%$ of distribution reserves and $77.5 \%$ of funds are ready to channel. Whereas the allocation for program activities in poverty alleviation efforts for the EcoCare program was 20\%, ICD by 5\%, YouthCare by 10\%, Ed- 
uCare by $22 \%$, HealthCare by $34 \%$ and National by $9 \%$. As a form of transparency and accountability, RZI reports on the progress of the programs that have been implemented by donors.

\section{CONCLUSION}

The trustworthy, transparent and professional ZIS management and distribution model has been carried out by Rumah Zakat Indonesia (RZI) so that RZI is one of the management bodies of ZIS that earns public trust. Through the development of an integrated ICD program, the distribution of ZIS can empower the poor. To control empowerment programs, RZI has established SOPs in order to control programs.

\section{REFERENCES}

1. Ali, N. M. (1993). Zakat (Tax) as an Instrument in Fiscal Policy. Thesis IAIN Sunan Kalijaga Yogyakarta.

2. Amanah, DSNI. (2010). Can Zakat Resolve Poverty," quoted from http://www.dsniamanah.or.id, accessed on 10 October 2019.

3. Bappenas. (1993). Theoretical Perspective of Local Economic Development Concepts. Jakarta: Bappenas.

4. Blank. (2004). Poverty, Policy and Palce: How Poverty and Policies to Alleviate Poverty are Shaped by Local Characteristics. RPRC Working Paper.

5. Effendi, S. (1988). Principles of Data Analysis. Jakarta: LP3ES.

6. Jurjani, A. M. (1983). Kitab al-Ta'rīf. Beirut: Dar al-Kutub al-'Ilmiyah.

7. Kuncoro, M. (2003). Development Economics: Theory, Problems and Policies. Yogyakarta: UPP AMP-YKPN.

8. Qadir, A. (2001). Zakat in the Mahdah and Social Dimensions. Jakarta: RajaGrafindo Persada.

9. Qardhawi, Y. (1995). Islamic Tips for Eradicating Poverty. Jakarta: Gema Insani Press.

10. Ravallion, M., Poverty Comparisons. World Bank, 2001.

11. Rumah Zakat Indonesia. (2011). Profile of Rumah Zakat Indonesia, quoted from http://www.rumahzakat.org, accessed on December 23, 2019.

12. Sabiq, S. (1982). Fiqh al-Sunnah, Volume I. Beirut: Dar al-Fikr.

13. Setyawan, S. (2006). Performance Measurement of Regional Government Financial Budget Viewed from the Accountability Perspective. Yogyakarta: UGM.

14. World Bank Report (2001). At tacking Poverty. Oxford: Oxford University Press. 